\title{
Leadership Style and Competence Against State Apparatus Performance (Study at the Regional Secretariat Office of North Barito Regency)
}

\author{
Normila $^{1}$, Hairudinor ${ }^{1}$, Siswanto Rawali ${ }^{1}$, Abdurrahman ${ }^{1}$ \\ ${ }^{1,}$ University of Lambung Mangkurat, Banjarmasin, Indonesia
}

Received: 4 March 2021

Article Info

Accepted: 31 March $2021 \quad$ Published: 9 April 2021

Keywords:
Leadership style
Competence
State apparatus performance

\begin{abstract}
Leadership is a key factor in the success of an organization and management that directs the work of organizational members to achieve organizational goals. Measurement of organizational performance needs to be carried out in ensuring the understanding of the implementers and measuring achievement, ensuring the achievement of an agreed performance scheme, monitoring and evaluating performance with a comparison between work and implementation schemes, providing objective rewards and punishments for performance achievements that have been measured according to the measurement system has been agreed upon, making it a means of communication between employees and leaders in an effort to improve organizational performance, ensure that decisions are made objectively and reveal problems that occur. This study proves that terdapat significant influence simultaneously and there is a partial significant influence leadership style and competence on the Performance of Administrative At the Regional Secretariat North Barito regency of $66.3 \%$ while the remaining $33.7 \%$ is influenced by other variables that are not included in this research model. Leaders should continuously provide high motivation so that work is done well, provide polite service to the community, provide what the community needs, work in accordance with leadership directions and are willing to take full responsibility for the risks in every work done.
\end{abstract}

\section{Copyright and License:}

Authors retain copyright and grant the journal right of first publication with the work simultaneously licensed under a Creative Commons Attribution 4.0 International License that allows others to share the work with an acknowledgment of the work's authorship and initial publication in this journal.

\section{INTRODUCTION}

The role and position of Civil Servants (PNS) is very important and decisive because civil servants are an element of the state apparatus in carrying out government and development tasks in order to achieve national goals. The State Budget which is spent on behalf of Civil Servants has increased from year to year, coupled with the enactment of remuneration / performance allowances as a reward for the work that has been carried out. However, this has not been matched by increased professionalism and high integrity for the Civil Service Community. In an effort to overcome this problem, policy makers need to make internal improvements, one of which is through human 
resource development (HR). The improvement of internal conditions at the same time aims to strengthen oneself and increase resilience in facing local and global competition which will inevitably be tighter, because the success of agencies in improving the performance of their institutions is highly dependent on the quality of the human resources (HR) concerned in their work and work. Work is a human activity to change certain conditions from a natural environment. In the process of achieving the desired needs, each individual tends to be faced with new things that may not be predicted beforehand, so that through work and experience growth, a person will gain progress in his life. It is in the work process that a person can be seen how their performance is. Every organization, both public and private, is formed to achieve certain goals, and if it is achieved then it can be said to be successful.

One of the ways that agencies do to improve performance and create work motivation to achieve high achievement and loyalty for their employees is by applying fair and proper leadership principles and employee professionalism that must be improved so that employee performance can be better. Leadership is closely related to the survival of an agency. Leadership is a universal phenomenon found in collective life. Leadership has a huge influence on organizational and group life. To achieve common goals, people in the organization need to foster togetherness by following the control of their leaders. With this control, different desires, desires, wills, feelings, needs, etc. are brought together to be moved in the same direction by a leader to achieve common goals. The leadership style is identical to the attitude of a leader in leading an organization. In general, many leaders adjust their leadership style to the conditions of the organization being led. There is even a leader who has more than one leadership style in an effort to achieve organizational goals. (Rivai 134: 2013).

Leadership is a key factor in the success of an organization and management that directs the work of organizational members to achieve organizational goals. Good leadership is believed to be able to bind, harmonize, and encourage the potential of organizational resources so that they can compete well. This is a human factor that binds together as a group and motivates them to achieve their goals. According to Wahjosumidjo, (2012: 35). "Leaders are a process between relationships or interactions between leaders, subordinates and situations -

In addition, to achieve success, a strong foundation in the form of competence is needed. Thus, competence becomes very useful to help organizations improve their performance. Competence is needed in every human resource process. The more competencies are considered, the more performance will be increased (Spencer, 1993). In this case, the role of a leader is the caretaker in building the enthusiasm of his subordinates to work to achieve company goals. All of these are several reasons for the decline in employee performance at work. A leader must apply a leadership style to manage his subordinates, because a leader will greatly influence the success of the organization in achieving its goals. Leadership style is the behavior or method that is chosen and used by the leader in influencing the thoughts, feelings, attitudes and behavior of the members of the subordinate organizations (Nawawi, 2003: 115).

As we know in the scope of Regional Government that within a certain period of time, leaders / officials in each Service / Office are always rolling positions, where each new leader has a different leadership style, so that each leadership style has a positive or negative impact on employee performance. One of the problems that occur in government agencies is where the leader in carrying out leadership in his power in the form of the authority to demand compliance in giving assignments 
to employees seems rigid and in accordance with procedural and sometimes authoritarian. In addition, leaders do not understand subordinates who have different characteristics such as abilities, knowledge of attitudes and behaviors so that they have difficulty getting to know their subordinates. According to Rukmana in Pasolong (2010: 118) that in a good bureaucracy it is expected that officials / leaders who can act as leaders are obliged to attend a series of training by the leaders at each level. In accordance with PP. 101 of 2000 that leadership training (education and training) is intended to achieve the requirements of bureaucratic leadership in order to achieve good agency performance. By following a series of leadership training, it is hoped that officials / leaders can act as leaders who carry out their leadership functions with all their skills and attitudes and not just a leader who only holds a position. The employee competency aspect is also an important aspect in improving performance where in today's globalization era, of course, the needs of each employee will increase with the times.

Competence has a very important role, because in general competence involves a person's basic ability to do a job (Moeheriono, 2009). So far, many government agencies do not have employees with adequate competence, this is evidenced by the low productivity of employees and the difficulty of measuring employee performance (Sriwidodo and Agus Budhi, 2010). To achieve maximum and satisfying work results, an employee's competencies are needed in carrying out their work tasks so that employee performance can increase. Bernard (1999) argues that expressions such as output, performance, efficiency, effectiveness are often associated with productivity. Productivity is the ratio of output to input. Performance emphasizes the value of efficiency, which is defined as the ratio of output to input, while efficient measurement replaces the determination of these outcomes. Apart from efficiency, productivity is also associated with the quality of output as measured by several predetermined standards. So what is meant by employee performance is the work results that can be achieved by a person in an organization in accordance with their authority and responsibility in order to achieve the goals of the organization concerned, legally, does not violate the rules, and is in accordance with morals and ethics.

Performance has an important meaning for employees, the existence of a performance appraisal means that employees get the attention of superiors, besides that it will increase employee morale because with this performance appraisal it is possible that high-performing employees are promoted, developed and rewarded for performance, otherwise employees who do not perform well may be demote. The difficulty in measuring the performance of public service organizations is because the goals and missions of public organizations are often not only very vague, but also multidimensional because the stakeholders of public organizations have different interests so that the performance measurement of public organizations in the eyes of stakeholders is also different. Measurement of organizational performance needs to be carried out in ensuring the understanding of the implementers and measuring achievement, ensuring the achievement of an agreed performance scheme, monitoring and evaluating performance with a comparison between work and implementation schemes, providing objective rewards and punishments for performance performance that has been measured according to the measurement system has been agreed upon, making it a means of communication between employees and leaders in an effort to improve organizational performance, ensure that decisions are made objectively and reveal problems that occur. Based on the above problems, it can be seen that the importance of leadership style and competence on employee performance, therefore the researcher wants to conduct research with the title "The Effect of Leadership Style and Competence on the Performance of State Apparatus (Study at the Regional Secretariat Office of North Barito Regency)". 


\section{METHODOLOGY}

This research uses a quantitative approach, namely a research method based on the philosophy of positivism, which is used to examine a specific population or sample (Sugiyono, 2009: 14). In addition, this study used a survey method, because the information was collected from respondents using questionnaires. This type of research is explanative research using a quantitative approach. The explanative research according to Sugiyono (2015: 9 0) is research that explains the causal relationship between the variables that affect the hypothesis. This research was conducted at the Regional Secretariat Office of Barito Utara Regency, Central Kalimantan Province. Population and sample in this study were employees at the Regional Secretariat Office of Barito Utara Regency, Central Kalimantan, totaling 50 respondents as the research sample. For sampling in this study, taken from all sections in the organizational structure of the Regional Secretariat of North Barito Regency using theformula Proportional Allocation. Thetechnique samplingused in this study is to use nonprobability sampling, which means that all elements in the population do not have the same opportunity to be selected as samples (Ferdinand, 2006: 231). In the process of compiling this research, the data collection technique used was the questionnaire method. The questionnaire or questionnaire is a data collection technique which is done by giving a set of questions or written statements to the respondent to answer (Sugiyono 2009: 142).

Documentation, which is looking for data on things or variables in the form of notes, transcripts, books, newspapers, magazines, inscriptions, meeting minutes, agendas and so on (Arikunto, 2010: 274). Sources of data in study thisare divided into two types, namely primary data sources and secondary data sources. According to Nazir (2011: 153) Primary data is a source of research data obtained directly from the original source. Primary data in this study is data obtained directly from respondents through questionnaires. Secondary data in this study were obtained through literature studies from literature books, journals, the internet, and articles that support research. The instrument used in this study was a questionnaire on a Likert scale. The use of the Likert scale is used to measure the attitudes, opinions and perceptions of a person or group of people about social phenomena. With a Likert scale, the variables to be measured are translated into indicators variable,then indicators theare used as a starting point to develop instruments - instruments that can be a statement or a question. (Sugiyono, 2012: 132-133).

\section{FINDINGS AND DISCUSSION}

\subsection{The Partial Effect of Leadership Style on Employee Performance}

In this study, the results of the test on hypothesis testing have proven that there is a significant influence of Leadership Style on the Performance of State Apparatus at the Regional Secretariat Office of North Barito Regency. This is indicated by the statistical value of the t test (4.033) which is greater than the t table (1.648) with a probability value of 0.008 , besides that theresults descriptiveof the respondents on thestatement variable leadership styleshow the total value of indicator achievements of $67 \%$ or category good.

International Journal of Politic, Public Policy and Environment Issues, Vol.1, No.1, April 2021 
From the results of this study, it shows that there is a similarity with previous research conducted by Aan Rahman, Siti Marfina Estirina (2018) regarding the influence of leadership style on employee performance, where the results of this study are that there is a strong relationship betweenstyle leadership and employee performance, based on the calculation of determination researched. The results of this study also support the theory put forward by Rivai (2014: 42) which states that leadership style is " a set of characteristics used by leaders to influence subordinates so that organizational goals are achieved or it can also be said that leadership style is a pattern of behavior and strategies that are preferred and often applied by a leader $\|$.

\subsection{Partial Influence of Competence on Employee Performance}

In this study, the results of the $t$ test on hypothesis testing have proven that there is a significant influence of competence on the performance of state apparatus at the Regional Secretariat Office of North Barito Regency. This is indicated by the statistical value of the test (2.679) which is greater than the t table (1.648) with a probability value of 0.011 , besides that theresults descriptiveof the respondents on thestatement variable leadership styleshow the total value of indicator achievements of $68 \%$ or category good. The results of this research test partially prove that competence has a significant and positive effect on the performance of the State Apparatus at the Regional Secretariat Office of North Barito Regency. The results of this study are supported by previous research conducted by Maria S. Sampe (2014) regarding the Effect of Competence on Employee Performance of Upt.Library University Hasanuddin, where the results of this study show that the quality of service consisting of knowledge, skills and attitudes either partially or simultaneously has a significanteffect positive on the performance of Hasanuddin University Librarians.

The results of this study also support the theory put forward by Boyatzis (1982) which defines competence as an ability possessed by a person who appears in his attitude in accordance with work needs within the parameters of the organizational environment and gives the desired results. According to the theory above, it can be explained that competence is an ability that must be possessed by every employee, both in the form of knowledge, skills, skills, attitudes and behaviors required in carrying out the main tasks, functions, authorities and responsibilities assigned to him. Employees who do not have competence find it difficult to complete the work assigned to them so that it will affect their performance in providing services to the community.

Therefore, the Regional Government of North Barito Regency, especially the Regional Secretariat of North Barito Regency, to improve the competence of its employees, strives for programs and activities such as carrying out bureaucratic reforms, various in-service training, functional training, technical training, workshops, seminars and other scientific activities. With the competencies possessed by each employee, it is hoped that employees can carry out their work well and can produce good performance. The implication in this research is how to maintain and improve competence so that the resulting performance is better.

\subsection{The Effect of Leadership Style and Competence together on Employee Performance}

In this study, the results of the F test on hypothesis testing have proven that there is a significant effect together of Leadership Style and Competence on the Performance of State 
Apparatus at the Regional Secretariat Office of North Barito Regency. This is indicated by the statistical value of the F test (4.791) which is greater than the F table (3.25) with a probability value of 0.014 , besides that theresults descriptiveof the respondents on the variable statement of leadership style and competence are $66.3 \%$ while the remaining $33.7 \%$ is influenced by other variables not included in this research model.

In this study, it is stated that the leadership style will significantly affect employee performance in a positive direction, as well as competence will affect the performance of the Office Staff of the Regional Secretariat of the North Barito Regency. The results ofstudy thissupport the theory according to House in Gary Yukl, (2009: 4) saying that "Leadership is an individual's ability to influence, motivate, and make others able to contribute to the effectiveness and success of the organization. The success of an institution or agency, either as a whole or in various groups in a particular institution or agency, really depends on the effectiveness of the leadership contained in the institution or agency concerned.

Therefore a leader is needed who can become the center of communication, to be able to convey his thoughts and desires to his surroundings and is otherwise sensitive sensitive to receive all information from his environment, because if a leader wants to impose his own thoughts or ideas and is not sensitive to cues the cue given by his environment, he must be not a good leader and that greatly affects the performance of his employees. The results of this study are supported by previous research conducted by Falilah Wahyono (2019) regarding the Influence of Organizational Culture, Motivation and Competence on Employee Performance of the Batang Regency Transportation Service. The result of this research is that organizational culture, competence and compensation have a joint effect on employee performance.

From the results above, it can be concluded that leadership style and competence have a significant influence on the performance of the Regional Secretariat of North Barito Regency both partially and simultaneously, this study shows that these variables need to be considered in order to continuously experience increased performance for the advancement of the agency.

Researcher admits personally that in this study there are limitations experienced by researchers in this study, namely the limitations of researchers in adding research variables in addition to the variables of Leadership Style, Competence and Performance of State Apparatus to be examined at the Regional Secretariat Office of North Barito Regency. In fact, the performance of state apparatus can be influenced by other variables such as physical and non-physical work environments, training / education and organizational culture. This research was only conducted at the Regional Secretariat Office of North Barito Regency so that the results of the study could not be generalized to other companies. 


\section{CONCLUSION}

Based on the results of the analysis, several conclusions can be drawn firstly, there is a partially significant influence of Leadership Style on the Performance of State Apparatus at the Regional Secretariat Office North Barito Regency. Secondly, there is a partially significant influence of Competence on the Performance of State Apparatus at the Regional Secretariat Office of North Barito Regency. Thirdly, there is a significant influence simultaneously and terdapat partial significant influence leadership style and competence on the Performance of Administrative At the Regional Secretariat North Barito regency of $66.3 \%$ while the remaining $33.7 \%$ is influenced by other variables that are not included in the model this research.

\section{REFERENCES}

Achmad, Zaenudin, 2009, Manajemen Sumber Daya Manusia, Cetakan ke 2, Penerbit Fajar, Jakarta

Agus Dwiyanto. 2008. Mewujudkan Good Governance melalui Pelayanan Publik.Yogyakarta : Gadjah Mada University Press.

Andrew Bernard and J. Jensen; Exceptional exporter performance: cause, effect, or both? ... Journal of International Economics, 1999, vol. 47, issue 1, 1-25.

Anwar Prabu Mangkunegara. 2005.SumberDaya Manusia perusahaan. RemajaRosdakarya: Bandung

Gibson, James, L., 1999, Organisasi, Perilaku, Struktur dan Proses, Edisi ke-5. Cetakan ke3. Jakarta: Erlangga Publisher.

Hasibuan,MalayuS.P2007,Manajemen Sumber Daya Manusia Perusahaan,Bandung, PT. Bumi Aksa.

Miftah Thoha. 2013 -Kepemimpinan dalam manajemen\| Jakarta : Raja Grafindo. Persada Moeheriono. 2009. Pengukuran Kinerja Berbasis Kompetensi. Bogor: Ghalia.

Spencer, LM and Spencer, SM (1993) Competence at Work Models for Superior Performance. John Wiley \& Sons, New York.

Sriwidodo, Untung dan Agus Budhi Haryanto. 2010. Pengaruh Komunikasi Dan Kesejahteraan Terhadap Kinerja Pegawai Dinas Pendidikan Kabupaten Sukoharjo. Jurnal Manajemen Sumber Daya Manusia Vol. 4 No. 148 Juni 2010: 47 - 57

Sutikno, sobry M.(2014).Pemimpin Dan Gaya Kepemimpinan, Edisi Pertama Lombok: Holistica

James AF Stoner, dkk. 1996. Manajemen, Edisi Bahasa Indonesia. Jakarta : PT. Prenhallindo.

James AF Stoner, 2003, Manajemen, Edisi Bahasa Indonesia, Jilid II, Gramedia Group,. Jakarta, 2003. Robbins, Stephen P, Perilaku Organisasi, Edisi kesepuluh.

Rofiatun dan Masluri. 2011. Pengaruh Iklim Organisasi Dan Kompetensi Pegawai Terhadap Kinerja Pegawai Dengan Mediasi Motivasi pada Dinas-Dinas Di Kabupaten Kudus. Jurnal Analisis Manajemen

Prawirosentono, Suryadi. 2008. Kebijakan Kinerja Karyawan. Yogyakarta:BPFE.

Veithzal Rivai, 2013, Manajemen Sumber Daya Manusia Untuk Perusahaan Dari Teori Ke Praktek, Rajagrafindo persada, Bandung

Wahjosumidjo. 1994. Kepemimpinan dan Motivasi. Ghalia Indonesia: Jakarta

Wahjosumidjo, 2010. Kepemimpinan Kepala Madrasah, Tinjauan Teoritik dan Permasalahannya, (Jakarta: Raja Grafindo Persada, 
8

Veithzal Rivai. 2014. Manajemen Sumber Daya Manusia untuk Perusahaan, Edisi ke 6, PT. Raja Grafindo Persada, Depok, 16956.

Yukl Gary. (2009). Kepemimpinan dalam Organisasi Edisi 5. (Alih Bahasa Budi Suprianto). Jakarta: Indeks 